ставлення навколишніх, тенденція до невротичності та виснаження психічної енергії в ході інтенсивного емоційного контактування, участь педагогів.

Феномен професійного самовизначення має розглядатися комплексно 3 професійним розвитком, як цілеспрямована активність індивіда 3 якомога більш повної реалізації своїх здібностей, можливостей у конкретному виді професійної діяльності. Базовим компонентом такої активності є усвідомлення ним вимог обраної професії, міри власної придатності до неї та перспектив власного професійного зростання.

\title{
Література
}

1. Гріньова О. М. Професійне самовизначення майбутніх педагогів як фактор успішності їх професійної діяльності / О. М. Гріньова // Проблеми загальної та вікової психології: збірник наукових праць Інституту психології ім. Г. С. Костюка АПН України / за ред. Максименка С. Д. - К. : Логос, 2008. - Т. Х. - Ч.2. - С. 168-179. 2. Карнизова Л. М. Самоопределение профессионала в проблемной ситуации / Л. М. Карнизова // Вопросы психологии. - 1990. - № 6. - C.75-82. 3. Поташник М. М. Управление профессиональным ростом учителя в современной школе : [метод. пособие] / M. М. Поташник. - M. : Центр педагогического образования, 2009. - 448 с. 4. Bandura A. Social foundation of thought and action : A social cognitive theory. - N.Y., 1986. - Englewood Cliffs, Prentice-Hall.ISBN 9780138156145. ISBN 013815614X, OCLC $12080269-617$ p.

Олександр Коваленко

\section{СУЧАСНИЙ СТАН ПРОБЛЕМИ ФОРМУВАННЯ ПРОФЕСІОНАЛІЗМУ МАЙБУТНІХ ЕКОНОМІСТІВ}

Коваленко О. В. Сучасний стан проблеми формування професіоналізму майбутніх економістів.

У статті проаналізовано сучасний стан проблеми формування професіоналізму майбутніх економістів, розглянуто чинники, що визначають рівень підготовленості економіста до професійної діяльності, виокремлено рівні професійної спрямованості студентів, а також визначено критерії сформованості професійних знань студентів економічних спеціальностей.

Ключові слова: структура діяльності економіста, професійно значущі якості фахівця, професійна спрямованість студентів.

Коваленко О. В. Современное состояние проблемы формирования профессионализма будущих экономистов.

В статье проанализировано современное состояние проблемы формирования профессионализма будущих экономистов, рассмотрены факторы, определяющие уровень подготовленности экономиста к профессиональной деятельности, выделены уровни профессиональной направленности студентов, а также определены критерии сформированности профессиональных знаний студентов экономических специальностей.

Ключевые слова: структура деятельности экономиста, профессионально значимые качества специалиста, профессиональная направленность студентов.

Kovalenko O. V. Modern state of problem of forming of professionalism of future 
economists.

The modern state of the problem of forming of the future economists' professionalism is analyzed by the author in this article, the factors defining the level of an economist's qualification for the occupational activity are examined, the levels of the students' occupational directedness and the criteria of the formedness of the occupational knowledge of the students of the economical specialties are also defined.

Key words: structure of an economist's activity, specialist's occupational significant qualities, students' occupational directedness.

Проблеми зміни орієнтації суспільних відносин, що відбулися в нашій країні, виникнення нових завдань, які життям висуваються перед суспільством, спонукають до переосмислення цілей і завдань змісту та організації сучасного навчання на всіх його щаблях, зокрема у вищій школі, яка покликана готувати фахівців. У сучасному суспільстві немає жодної сфери життя, жодної професії, де людина могла б почувати себе незалежно від світу економіки, могла б жити, не враховуючи їі закони. Нині не викликає сумніву, що нові покоління, які вступають у життя, у світлі сучасних тенденцій повинні бути зорієнтовані в економічній галузі задля більш оптимального застосування своєї праці. Рівень підготовки фахівців має відповідати не тільки поточному стану суспільних і виробничих відносин, а й забезпечувати здатність фахівців: адаптуватися у процесі оновлення й зміни економічної та виробничої сфери країни; знаходити рішення в нестандартних ситуаціях; самостійно і творчо мислити. Це завдання необхідно розв'язувати як під час побудови системи освіти, так і загалом в процесі визначення змісту кожної дисципліни окремо.

Аналіз останніх досліджень і публікацій, у яких започатковано розв'язання окресленої проблеми показав, що сучасна педагогічна наука за останні роки збагатилася низкою теоретичних досліджень оптимізації процесу професійної підготовки фахівців в умовах бурхливого зростання інформації, швидкої зміни техніки i технології, а саме: методом ефективного використання теоретичних узагальнень (Г. Корнєв, В. Давидов та ін.); проектуванням нових педагогічних технологій, зорієнтованих на досягнення запланованого результату (В. Беспалько, Ю. Чернова, Л. Глухова, Ю. Кустов та інші); побудовою безперервної освіти та реалізації спадкоємності в навчанні, що забезпечує цілісність процесу навчання і його результат (В. Ледньов, Н. Бахарев та ін.); формуванням професійно спрямованого змісту освіти (С. Архангельський, Н. Тализіна та ін.).

Метою статmі є аналіз сучасного стану проблеми формування професіоналізму майбутніх економістів.

У межах етапу науково-технологічної революції знання, у традиційному їх розумінні як мети навчального процесу, змінюють свій сенс. Метою підготовки постає діяльність, здатність до іiі розбудови, особистісні якості, що визначають не тільки професійні характеристики фахівця, але насамперед його соціокультурні домінанти.

Здійснений дослідником Е. Башкаєвою аналіз наукових досліджень у галузі психології та теорії професійної підготовки дозволив встановити, що модель формування особистості сучасного фахівця повинна бути заснована на загальній структурі діяльності, а також на особливостях структури економічної діяльності, підгрупи фахівців цієї галузі і якостях, необхідних для здійснення цієї діяльності та динаміки іiі розвитку. На основі моделі професіограми економічної діяльності, розробленої науковцями Санкт-Петербурзького університету, структура діяльності 
економіста покладена в основу моделі формування професійно значущих якостей особистості фахівця [1]. Структура діяльності економіста реалізується в чотирьох компонентах професійних умінь: проектувальних, конструктивних, організаторських, гностичних. Його професійна майстерність передбачає успішне розв'язання завдань відповідно до цілей, що стоять перед суспільством, високий рівень мотивації професійної діяльності та вміння вирішувати економічні завдання.

Чинниками, що визначають рівень підготовленості економіста до професійної діяльності $є$ :

- вираженість професійної спрямованості (мотивації) та професійно значущі якості особистості фахівця;

- рівень фундаментальної (базової) підготовки;

- рівень знань і навичок у сфері майбутньої діяльності;

- рівень активності самоосвіти.

Аналіз системи професійних умінь фахівця виявив зміст діяльності і дозволив визначити знання, вміння та навички, які необхідно формувати в навчальновиховному процесі. Критеріями професійної значущості певних якостей особистості майбутнього фахівця $є$ :

- соціальна значущість певної професійної якості, яка задається у вигляді вимоги, що висувається до особистості фахівця;

- уплив цієї якості на успішність навчальної та майбутньої професійної діяльності і на можливість найбільш повної реалізації себе як особистості.

У результаті аналізу досліджень з'ясовано, що ефективний спосіб розвитку професіоналізму полягає у спеціальних вправах до початку діяльності, на окремих діях. Розв'язання проблеми формування професійно значущих якостей студента нами бачиться в цілеспрямованому педагогічному проектуванні, що передбачає розроблення навчального комплексу, наповненого елементами майбутньої професійної діяльності, який $є$ передумовою формування у студентів потрібної професійної якості. У комплексі повинні бути сплановані спеціально створені навчально-психологічні ситуації відповідальної залежності між студентами, колективом навчальної групи i педагогами, у результаті яких виявляються i розвиваються професійні якості студентів.

Ми згодні $з$ думкою Е. Башкаєвої [1], що основними групами чинників, які визначають розвиток професійно значущих якостей, $\epsilon$ :

1) внутрішні- мотиви, суперечності між реальними вимогами й уявленнями про майбутню професію та особистісними характеристиками;

2) зовнішні- соціальні та економічні, загальнокультурні (вимоги до особистості фахівця, ступінь розвитку сфери діяльності, суспільний престиж професіі);

3) процесуальні - організаційно-педагогічні чинники.

Зроблено акцент на останню групу чинників, пов'язаних 3 формами організації підготовки майбутніх економістів, до яких відносяться:

- теоретичні - лекції, семінари, консультації;

- спрямовані на практичну підготовку - лабораторні практикуми, ділові ігри, виробничо-технічні ситуації, виробнича практика;

- самостійні позааудиторні заняття, курсове та дипломне проектування.

Інтеграція науки, виробництва та освіти стимулює появу нових форм організації навчання в умовах виробництва, де студенти старших курсів виконують виробничі завдання щодо бухгалтерської звітності, прогнозування, аналізу фінансового стану 
реальних об'єктів.

Психолого-педагогічні механізми формування професійно значущих якостей здійснюються на основі застосування педагогічних технологій, зорієнтованих на розвиток професійного самовизначення i творчого потенціалу особистості, що враховують іiі індивідуально-психологічні характеристики. Професійна підготовка фахівців у ВНЗ повинна грунтуватися на ідеї цілісності особистості, а також постійного розвитку і вдосконалення особистості в ході професійної підготовки [2].

Відтак одним з важливих завдань професійної підготовки є розкриття потенціалу особистості, що забезпечує вдосконалення діяльності, а також і самої особистості.

Аналіз системних досліджень останніх років довів тезу про цілісність особистісної структури, високої корельованості всіх особистісних властивостей. У процесі наших досліджень визначені професійно значущі якості особистості, володіючи якими, випускник ВНЗ досягне певного рівня у професійній діяльності.

Проведене нами дослідження наявного і бажаного рівня забезпечення заданого рівня підготовленості фахівця з потрібними «еталонними параметрами», відбитими у кваліфікаційних характеристиках, визначило ту неузгодженість, яка має місце 3 погляду різних експертів («споживачів»- представників організацій i «виготовлювачів» - працівників ВНЗ). Кореляційний аналіз професіограми і думок експертів щодо професійно значущих якостей фахівця підтвердив залежність між інтегративними якостями особистості й успішною діяльністю, а також дозволив нам виокремити список із семи комплексів професійно значущих якостей чинників успішної діяльності: професійні знання та вміння, професійна спрямованість, відповідальність, активність, адаптивність, психологічна стійкість і комунікативність [1].

Досліджувана цілісність є структурою, яка представлена сімома самостійними взаємопов'язаними підструктурами - чинниками. Кожен фактор детермінується вхідними в нього якостями 3 високими оцінками значущості. Успішність діяльності фахівця визначається рівномірністю рівнів вираженості всіма сімома виокремленими чинниками, тобто деякою універсальністю, «гармонійністю» особистості випускника ВНЗ. Ранжування професійно значущих якостей на основі кореляційного аналізу дозволило встановити, що для підвищення якості підготовки випускників до професійної діяльності необхідно приділити особливу увагу формуванню таких цілісностей у структурі особистості студента, як професійна спрямованість i відповідальність. Розвиток професійної спрямованості студентів у ВНЗ визначається попереднім виявом позитивного ставлення до професії і цінними за цим ставленням мотивами [4].

У психолого-педагогічних дослідженнях Е. Башкаєвої, Н. Кузьміної зазначено, що успіх творчої діяльності особистості багато в чому залежить від позитивного ставлення до справи, а також те що й самі функціональні можливості людини можуть бути визначені лише за цієї умови, що ділові якості $\epsilon$ результатом не тільки здібностей, але й бажання реалізувати їх на практиці. Тому попередньо вивчено становлення професійної спрямованості. Задля цього досліджено мотиви вступу на економічний факультет і випуску з нього, визначено рівень задоволеності аспектами майбутньої роботи та особливостями підготовки до неї залежно від рівня професійної спрямованості, структури цієї спрямованості.

У роботах Н. Кузьміної та Е. Башкаєвої виокремлено три рівні професійної спрямованості студентів:

1-ий - студенти 3 позитивною професійною спрямованістю на інженерно- 
економічну діяльність, що передбачає зв'язок між домінуючими, провідними мотивами з вмістом професійної діяльності;

2-ий рівень - студенти, для яких прийнятний компроміс між негативним ставленням до професії у процесі навчання у ВНЗ і перспективою надалі працювати за фахом;

3-ій рівень - студенти 3 негативним ставленням до професії інженераекономіста $[1 ; 4]$.

Перший рівень складають студенти четвертих і п'ятих курсів, другий рівень перших і других курсів, третій- студенти третього курсу. Аналіз задоволеності різними аспектами майбутньої спеціальності й підготовки до неї показав, що для студентів першого рівня значущими є такі аспекти діяльності, як відповідальність, активність, професійна спрямованість, комунікативність.

Для студентів другого рівня характерна невпевненість у відповідності своїх здібностей характеру майбутньої діяльності. Немає впевненості в правильності вибору спеціальності. Майже всі студенти третього рівня або переводились на інші факультети, або переведені через слабку успішність, або це - відтермінування армії.

Окрім трьох рівнів професійної спрямованості, Н. Кузьміна і Е. Башкаєва виокремлюють три етапи розвитку мотиваційно-ціннісного ставлення до професії. Першому етапу (I, II курс) характерні високі показники навчальних і професійних мотивів, які керують навчальною діяльністю. Другий етап (III курс) - це зниження інтенсивності всіх мотиваційних компонентів. Пізнавальні та професійні мотиви перестають управляти навчальною діяльністю. Третій етап (IV-V курс) - зростає рівень усвідомлення й інтеграції різних мотивів навчання.

У результаті теоретичного аналізу встановлено, що для вдосконалення процесу формування професійної спрямованості, крім відомої диференціації здібностей, необхідна диференціація мотиваційної сфери особистості. Результати експериментальної роботи підтвердили, що на професійну спрямованість великий уплив мають такі особистісні якості, як здібності і риси характеру.

Доведено, що основним психолого-педагогічним механізмом у формуванні професійної спрямованості $€$ суперечність між змістом професійної праці й особистісним змістом вибору професії.

Для розв'язання цієї суперечності і забезпечення динаміки розвитку професійної спрямованості в умовах ВНЗ пропонується: поглиблення особистісного сенсу вибору; коректування мотивації, акцент на домінуючий мотив, що стосується об'єктивного змісту діяльності; формування прямих мотивів діяльності; визначення перспективи діяльності.

Чим більше студент у процесі практик та вивчення спеціальних дисциплін дізнається про свою майбутню роботу, чим більше опановує він навички фахівця під час виконання обов'язків, тим вищий рівень сформованості необхідних для його майбутньої діяльності якостей.

Критеріями сформованості професійних знань (методологічних, теоретичних, методичних, технологічних) є:

- рівень розвитку пізнавальної активності і спрямованості особистості;

- обсяг, узагальненість, системність професійних знань;

- характер мислення, відкритість пошуку, творче, нестандартне осмислення дійсності;

- уміння переносити знання і використовувати їх у різних ситуаціях.

Підготовка фахівців економічного профілю високого класу у сфері бізнесу 
вимагає нових підходів у викладанні відповідних дисциплін, тому формування знань у галузі спеціалізації має поєднуватися 3 набуттям практичних навичок роботи на комп’ютерах під час розв'язання професійних завдань [3].

Підсумовуючи вищезазначене, можемо зробити висновки, що в навчальному процесі використовуються сучасні методичні матеріали. Зростання інформаційних технологій, використання обчислювальної техніки зумовлює постійну зміну форм організації навчального процесу і використовуваних методичних матеріалів. Питання підготовки кваліфікованих фахівців є для вітчизняної виробничої галузі одним 3 ключових.

Для того щоб рівень підготовки випускників відповідав сучасним вимогам, ВН3 необхідно вдосконалювати й актуалізувати навчальні програми як у галузі інформатики загалом, так і в частині дисциплін, присвячених практичним питанням автоматизації підприємств. Якщо автоматизація власне бухгалтерського обліку або маркетингу викладається широко, то, наприклад, постановці первинного, оперативного або торгового обліку в програмах ВН3 приділяється поки що недостатньо уваги, хоча на практиці ці спеціальності затребувані.

\section{Література}

1. Башкаева Э. Х. Разработка профессионально значимых качеств у студентов / Э. Х. Башкаева // Личностно-ориентированный подход в воспитании и образовании. 2011. - С. 86-92. 2. Беспалько В. П. Педагогика и прогрессивные технологии обучения / В. П. Беспалько. - М. : ИРПО, 2005. - 332 с. З. Кикоть В. Я. Проблемы управления и пути развития профессиональной подготовки слушателей вузов : [монография] / В. Я. Кикоть. - СПб. : Санкт-Петербургская академия МВД России, 1997. - 205 с. 4. Кузьмина Н. В. Методы исследования педагогической деятельности / Н. В. Кузьмина. - СПб. : Машиностроение, 1999. - 302 с.

УДК: 371.937

Наталя Колесниченко

\section{КОНЦЕПЦІЯ МОДЕРНІЗАЦЇ̈ ПРОФЕСІЙНОЇ ПІДГОТОВКИ БАКАЛАВРІВ РОМАНО-ГЕРМАНСЬКОЇ ФІЛОЛОГІЇ НА ЗАСАДАХ КОМПЕТЕНТНІСНОГО ПІДХОДУ}

Колесниченко Н. Ю. Концепція модернізації професійної підготовки бакалаврів романо-германської філології на засадах компетентнісного підходу.

У статті висвітлено проблеми вдосконалення професійної підготовки бакалаврів романо-германської філології. Приділено увагу проектуванню концептуальної моделі модернізації професійної підготовки бакалаврів романо-германської філології на засадах компетентністного підходу. Уточнено провідні етапи, загальнодидактичні та специфічні принципи організації означеного процесу.

Ключові слова: модернізація, професійна підготовка, бакалаври романогерманської філології, компетентністний підхід, лінгвокомунікативна компетентність.

Колесниченко Н. Ю. Концепция модернизации профессиональной подготовки бакалавров романо-германской филологии на основе компетентностного подхода.

В статье отражены проблемы совершенствования профессиональной подготовки бакалавров романо-германской филологии. Уделяется внимание проектированию концептуальной модели модернизации профессиональной подготовки бакалавров романо-германской филологии на основе компетентностного подхода. 